\title{
Lethal Autonomous Weapons Systems: Organizational and Political Consequences
}

\author{
Paul Dumouchel
}

Ritsumeikan University, Kyoto, Japan

\begin{abstract}
Focusing on existing 'autonomous' weapons systems and their uses replaces speculations about future developments and about what robots will or will not be able to do, with attention to the way these weapons are changing and have already changed warfare. The aspects of these transformations that will interest me in this paper are some of the political, organizational and social consequences of the introduction and deployment of various automatic and autonomous weapons systems. Beyond the questions of responsibility and legality, I want to look at the ways in which these weapons change countries' ability to project power, on how they affect the composition of armed forces, the power relationships within them, and their relations with other major political actors.
\end{abstract}

\section{Keywords}

Conflict; Lethal Autonomous Weapons Systems; Politics; Violence; War.

\section{DOI: 10.22618/TP.PJCV.20215.1.139006}

The PJCV Journal is published by Trivent Publishing

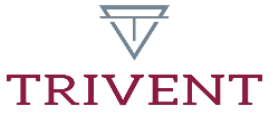

This is an Open Access article distributed in accordance with the Creative Commons Attribution Non Commercial (CC$B Y-N C$-ND 4.0) license, which permits others to copy or share the article, provided original work is properly cited and that this is not done for commercial purposes. Users may not remix, transform, or build upon the material and may not distribute the modified material (bttp:/ / creativecommons.org/ licenses/by-nc/4.0/) 


\title{
Lethal Autonomous Weapons Systems: Organizational and Political Consequences
}

\author{
Paul Dumouchel \\ Ritsumeikan University, Kyoto, Japan
}

\begin{abstract}
Focusing on existing 'autonomous' weapons systems and their uses replaces speculations about future developments and about what robots will or will not be able to do, with attention to the way these weapons are changing and have already changed warfare. The aspects of these transformations that will interest me in this paper are some of the political, organizational and social consequences of the introduction and deployment of various automatic and autonomous weapons systems. Beyond the questions of responsibility and legality, I want to look at the ways in which these weapons change countries' ability to project power, on how they affect the composition of armed forces, the power relationships within them, and their relations with other major political actors.
\end{abstract}

\section{Keywords}

Conflict; Lethal Autonomous Weapons Systems; Politics; Violence; War.

\section{Introduction}

Autonomous weapons and military robots (killer robots) are often seen as the stuff of science fiction, but as in the case of numerous science fiction books and movies, they are also viewed as something that will soon be true, intimations of a future that is upon us. Therefore, the argument goes, we should already prepare for what is to come and ethical reflection urgently needs to anticipate the consequences of such innovations. This 'preemptive turn' in ethics is not limited to the domain of military robots but can also be found in many other areas where technology is changing, or is expected to change rapidly, for example, protocells and artificial life, ${ }^{1}$ nanotechnology ${ }^{2}$ or social robotics. ${ }^{3}$ In all these cases it is argued that we already need to prepare for what is to come and that ethical reflection must anticipate future development to protect us from the unwanted consequences of these technological changes. For example, Wallach and Allen in the introduction to Moral Machines Teaching Robots Right from Wrong say that they want "to draw attention to the need for work on moral machines to begin now, not twenty to a hundred years from now when technology has caught up with science fiction." 4

\footnotetext{
${ }^{1}$ See M. Bedau, E.C. Parke (eds.), The Ethics of Protocells (Cambridge: MIT Press, 2009).

2 D. O'Mathuna, Nanoetbics big etbical issues with small technology (London: Continuum, 2009).

${ }^{3}$ W. Wallach, C. Allen, Moral Machines Teaching Robots Right from Wrong (Oxford: Oxford University Press, 2009).

${ }^{4}$ Ibid., 6.
} 
So far, two major issues have been at the center of ethical and legal debates concerning military robots. One is the question of responsibility whether moral or legal. Should the decision to take away a human life be transferred to a machine, to a lethal autonomous weapons system (LAWS) or should there always be a human 'in the loop'? If it is the robot that 'decides' autonomously, who will be responsible? Can an autonomous robot be responsible? What would it mean to say that a machine or autonomous system is responsible? ${ }^{5}$ If robots and other lethal machines cannot be responsible, can they be subject to international humanitarian law ${ }^{6}$ or to the laws of war, either just in bello or just ad bellum? ${ }^{7}$ Therefore - and this second issue has largely dominated the public debate - autonomous killing machines should be banned and declared illegal. ${ }^{8}$ This proposal is supported not only by many authors, but also by a significant portion of the public, numerous states, and international organizations. There now is a major international campaign to "Stop Killer Robots" that has gained approval from 30 countries, 26 Nobel prizes winner, 4,500 AI experts as well as many others, religious leaders and United Nations officials. ${ }^{9}$

In principle, foresight is a good thing and evaluating the consequences of one's action has always occupied a central place in moral thought. Yet, apart from the fact that the future is unknown and that authors may be stoking some unfounded fear, how well founded is the claim that 'reality will one day catch up with science fiction'? Can this be considered a serious hypothesis to guide research in ethics, or is it more of a dream, whose premonitory truth Wendell and Collin among many others apparently take for granted? Should we also? Warnotte, for example, reminds us that there presently exists no definition of lethal autonomous weapons in international law, and that the only consensus that can be found in international fora concerning autonomous weapon systems (lethal or otherwise), is that such weapons do not yet exist. ${ }^{10}$ It is true that this negative consensus rests to a large extent on disagreement concerning the meaning of 'autonomous. ${ }^{11}$ Nonetheless, as Jeangène Vilmer says "Any attempt to base today an interdiction on an unproven risk from of a weapon that does not yet exist is by definition doomed to failure."12

\footnotetext{
5 See M. Coeckelgergh, "From Killer Machines to Doctrine and Swarms or Why Military Ethics is not (necessarily) about Robots," Philosophy \& Tecbnology 24 (2011) 24:269-278 ; P. Dumouchel, "Philosophy and the Politics of Moral Machines," Journal of Artificial Intelligence Humanities 4 (2019):31-50 ; R. Sparrow, "Killer Robots," Journal of Applied Philosopby 24/1 (2007): 62-77.

${ }^{6}$ H-Y. Liu, "Categorization and Legality of Autonomous and Remote Weapons System," International Review of the Red Cross 94 (June 2012): 627-652.

${ }^{7}$ B.J. Steele, E.A Heinze, "From Smart to Autonomous Weapons." in The Future of Just War. New Critical Essays, ed. Gentry \& Eckert (Athens, GE: University of Georgia Press, 2014), 98-114.

${ }^{8}$ M.A. Gubrud, "Stopping Killer Robots," Bulletin of Atomic Scientists 70/1 (2014): 32-42.

9 According to the latest visit to the organization's web site (www.stopkillerrobots.org_ Oct. 17, 2020), the campaign is now supported by: 30 countries, $110+$ NGOs, 4,500 AI experts, the United Nations Secretary General, the European Parliament, Human Rights Council Rapporteurs (HNHRC), 26 Nobel laureates and $61 \%$ of the public.

${ }^{10}$ P. Warnotte, "SALA: aspects juridiques," in Robotisation des Armées enjeux militaires, éthiques et légaux, 127-146. See also P. Scharre, "Autonomous Weapons and Operational Risks." Center for New American Security (2016). Scharre states that "Autonomous weapons generally do not exists, and their military costs and benefits can be speculated but are not yet clearly known." (ibid., 4).

11 See the Third CCW Meeting of Experts on LAWS in Geneva 2016, www.unog.ch/ 80256EE600585943/\%28httpPages\%29/37D51189AC4FB6E1C1257F4D004CAFB2?OpenDocume nt . See also J.-B. Jeangène Vilmer, "Diplomatie des armes autonomes: les débats de Genève," Politique Etrangère 3 (2016):119-130.

12 [“Toute tentative de fonder aujourd'hui une interdiction sur un risque non-avéré d'armes qui n'existent pas encore est par nature vouée à l'échec. "] J.-B. Jeangène Vilmer, "Terminator Ethics: Faut-il interdire les 'robots tueurs'?’ Politique Etrangère 4 (2014):164.
} 
Further, as R. Crootof argues, the strong focus on the danger of future developments and the calls on a moratorium on research have hidden from view the fact that in many ways "Killer Robots' are here and that they are here to stay." "13 Weapons systems that, on the basis of the data they receive and process, can by themselves select and engage a target, are already part of the arsenal of many armed forces. For example, that of the United States, which defines 'autonomous weapon system' as a

weapon system that, once activated, can select and engage targets without further intervention by a human operator. This includes human-supervised autonomous weapon systems that are designed to allow human operators to override operation of the weapon system, but can select and engage targets without further human input after activation. ${ }^{14}$

Apart from the United States, such weapons have been developed by China, France, Germany, Iran, Israel, Russia, South Africa, South Korea and Venezuela among others. These have also been sold to many other countries. ${ }^{15}$ Their presence and standard usage in military operations, argues Crootof, change the discussion concerning their legality. To this day, their use did not give rise to strong public condemnation — for the most part the systems which are already in use are not included in the proposed ban - nor has it until now ever been challenged in international courts. The presumption then is that such weapons are legal. In consequence, the proposal to ban or to declare illegal future 'fully' autonomous weapons which do not yet exist, risk leaving to the side those weapons that already exist and are in use, and overlooks the need for their regulation.

Focusing on existing 'autonomous' weapons systems and their uses replaces speculations about future developments and about what robots will or will not be able to do, ${ }^{16}$ with attention to the way these weapons are changing and have already changed warfare. The aspects of these transformations that will interest me in the remainder of this short paper are some of the political, organizational and social consequences of the introduction and deployment of various automatic and autonomous weapons systems. Beyond the questions of responsibility and legality, I want to look at the ways in which these weapons change countries' ability to project power, on how they affect the composition of armed forces, the power relationships within them, and their relations with other major political actors. To put it in a different way, autonomous weapons systems do not only have consequences for those who are at the receiving end, but also for the institutions that resorts to them.

Questions of the responsibility for and of the legality of the use of such weapons do arise and they are fundamental. However, they should be answered in relation to the way, and to the circumstances, in which these weapons systems are used, rather than in principle as a mere consequence of the fact that these machines are, or are more or less, 'autonomous.' Like others, ${ }^{17} \mathrm{I}$ think that issues concerning the legality and responsibility for the use of the

13 R. Crootof, "Killer Robots are Here: Legal and Policy Implications," Cardozo Law Review (2015): 1843. 14 Defense, directive 3000.09, Autonomy in weapons systems (November 2, 2012): 13-14. http://www.dtic.mil/whs/directives/cores/pdf/300009p.pdf .

15 M.-d-N. Ruffo, "La robotique militaire: possibilités d'emploi et enjeux éthiques," in Robotisation des Armées enjeux militaires, éthiques et légaux, 19-38.

16 For example, whether or not autonomous robots will be able to respect the principle of proportionality (Steele \& Heinze, 2014) or able to distinguish between civilians and combatants or recognize that a soldier is wounded or wants to surrender (Lambert, 2020). See B.J. Steele, E.A Heinze, "From Smart to Autonomous Weapons" ; D. Lambert, "La théorie de la guerre juste et les robots armés," in Robotisation des armées, enjeux militaires, éthique et légaux, 165-178.

${ }^{17}$ P. Warnotte, "SALA: aspects juridiques." ; J.-B. Jeangène Vilmer, "Terminator Ethics: Faut-il interdire les 'robots tueurs'?". 
autonomous weapons systems which presently exists (and those which are likely to exist in the near future) are not radically different from those which arise from the use of other complex weapon systems. As the American definition quoted above clearly states, 'autonomous' weapons are those which once activated can select and engage a target by themselves. It is among humans, and among humans only, that we should look to attribute responsibility either for the legal or the illegal use of such weapons. ${ }^{18}$

Th. Mahnken in Tecbnology and the American Way of W ar since 1945 argues that technological innovations are both avidly sought and resisted by the military. ${ }^{19}$ Which innovations are ultimately accepted and to what extent depend on the political states of affair, both national and international, as well as on the culture of the armed forces. Technological changes do not take place in a void. Though there is today a tendency to consider that AI changes everything, its rapid adoption in the military as in other domains, also reflects long term on-going social and military trends. Autonomous weapons systems are not only technological innovations, they are also responses to demands addressed to the armed forces by other social and political actors. To understand the consequences and to anticipate some of the future effects of these technological innovations we also need to take into account these dimensions which exclusive focus on the fact that these weapons are 'autonomous' tends to obscure. Autonomous as they may be, killer robots are weapons, that is tools that are used by humans against other humans.

\section{Autonomous and Semi-Autonomous: Anti-Missiles Missiles Systems, Drones and 'Fire-and-Forget' Systems}

Perhaps the best known, and currently the most used autonomous weapons systems are antimissiles missiles batteries, like the US army's Patriot or the navy's CIWS/Aegis systems. ${ }^{20}$ In both cases the system is able to recognize a hostile object, to target and then engage it on its own. However, at this time whenever these weapons are deployed and used there is always a human in the loop who needs to authorize and who can veto the launch. This does not mean that the system is not 'autonomous,' but that for various reasons the military has decided to use the system 'semi-autonomously,' rather than to its full capacity. In fact, the Aegis system has a 'casualty' mode where it is assumed that the human operator has been incapacitated, from then on, the system is on its own. The weapon's range of action, whether it is used semiautonomously or not, is strictly limited by its technical characteristics and by the use or purpose for which it was designed. In this case to destroy incoming enemy planes or missiles.

Some drones, unmanned aerial vehicles (UAV), are fully autonomous, but for now only as reconnaissance instruments. They are autonomous as far as flying to their destination and as far as their mission of observation and surveillance are concerned. However, firing, engaging the target is always remotely controlled. Autonomous as reconnaissance instruments, they are semi-autonomous as offensive weapons. In this case also that the system is only semi-autonomous is not an absolute technical limitation, but an option that we have chosen. These drones could be modified to be able to engage enemy targets on their own, if, at this point, they do not it is because we - humans, the military — have decided otherwise. However, the fact that at this time drones are unable to take offensive action on their own

\footnotetext{
18 P. Warnotte, "SALA: aspects juridiques," 144.

19 Th.G. Mahnken, Technology and the American Way of War since 1945 (New York: Columbia University Press, 2010).

20 The U.S. are not the only one with this technology: Russia's AK-630, the Netherlands' Goalkeeper, and Italy's DARDO are similar weapon systems. Germany also employs the NBS MANTIS, a landbased, fully automated air defense system that will detect, track and shoot the projectiles within a close range. See R. Crootof, “Killer Robots are Here: Legal and Policy Implications”:1870.
} 
changes, I believe, very little to the consequences of their massive introduction into the armed forces ${ }^{21}$ or to their use by the CIA to project American political power overseas.

Many of the American drones that fly in Iraq, Afghanistan, Yemen or Pakistan are remotely controlled from a base in Nevada, halfway across the globe from where they operate. In some case, drone pilots are not military personnel, but hired by private contractors, though this seems to be less and less the case since the armed forces regularly complain that there is a lack of drone pilots and sensor operators, due in part to the fact that private contractors offer much higher salaries that those of army or of the air force. ${ }^{22}$ To my knowledge, it is not entirely clear who can authorize a strike, only a military officer who supervises a number of pilots or the pilots themselves. It is even less clear whose "call it is." Once a strike has been authorized it may or may not take place for a variety of reasons, perhaps a troop of children just came out of a nearby school and the strike is aborted. Though it is the pilot who pulls the trigger, it is the sensor operator sitting adjacent who targets the laser and maintains the aim while the missile descends. This creates uncertainty which makes it difficult to determine exactly who is responsible for a strike, who should be blamed when what was thought to be a gathering of enemy combatants turns out to have been a tribal wedding.

To the opposite, Dewyn claims that with tele-operated drones no responsibility gap is possible, since whenever a drone strike is carried out, everything is recorded at the level of the operators in order to later evaluate the results of the attack. In consequence, in principle no war crime should be able to escape scrutiny. ${ }^{23}$ Unlike what is the case for soldiers on the ground, here who pulled the trigger and in what circumstances is always perfectly clear. However, neither the problem of responsibility, nor its solution are merely technical, but as Enemark argues essentially political. ${ }^{24}$ The lack of transparency concerning the use of lethal drones, either by the armed forces or the CIA is a political choice, rather than the direct consequence of particular technical innovations. UAVs allow countries to project power abroad in a novel manner that did not exist before. However, the way in which they decide to claim and to attribute responsibility for such distant use of their military power has little to do with whether or not the drones are 'fully' autonomous.

A third class of existing and used autonomous weapons may be described as "fire and forget" or "lock-on-after-launch" systems, like the UK Brimstone or the Israeli Harpy Loitering Weapon that detects and targets enemy radar emitters. Once launched such weapons will on their own identify and engage their targets. There are also sea based autonomous weapons systems, for example the PMK-2 type sea mine which when activated by a passing ship will on its own determine its target and fire a torpedo to destroy the ship. Here, as with traditional landmines, and unlike what is the case with the Brimstone and Harpy systems, the identity of the target is completely unknown to the deployer of the weapon. The Harpy Loitering Systems targets enemy radar emitters, while the Brimstone searches for

21 Enemark reports that 24 countries now possess armed drones, that 13 have used them and that production has expanded beyond the USA to countries including, Israel, India, Iran, Pakistan, South Africa, China, Russia and Turkey. C. Enemark, "On the responsible use of armed drones: the prospective of moral responsibilities of states," The International Journal of Human Rights 24 (2019) : 868-888

22 J. Schogol, "Contract jobs for drone pilots are often overseas." Air Force Times (April 21, 2015), https:/ /www.airforcetimes.com/news/your-air-force/2015/04/21/contract-jobs-for-drone-pilots-

are-often-overseas/. He adds that "( $\mathrm{m}$ ) any of the jobs advertised for drone operators are for overseas assignments in undisclosed locations for undisclosed clients." See also C. Enemark, "Drones, risk and moral injury," Critical Military Studies 5/2 (2019): 150-167.

23 M. Dewyn, "La théorie de la guerre juste et l'utilisation des drones armés: l'application des principes du jus ad bellum," in Robotisation des armées, enjeux militaires, éthique et légaux, 83-104.

24 Enemark, "On the responsible use of armed drones: the prospective of moral responsibilities of states." 
targets comparing them with target's signature in its memory. The targets therefore are not precisely known, but they are not completely unknown unlike what is the case with a mine.

Finally, there are other less well-known systems, like the South Korean SGR-1 sentinel robot that patrols the demilitarized zone between the two Koreas. It can detect a human presence at more than one kilometer even at night and destroy the target from that distance. However, it will verbally engage the target before deciding to fire or not and when it does that it also establishes communication with a human operator who will ultimately decide. It seems, but that is not entirely clear, that the SGR-1 Sentinel could also operate in a fully autonomous mode.

As can be seen from these examples, the question of the autonomy of the weapon systems is not only a technical one. All of the systems reviewed above could be used autonomously even if at this point they usually are not. It is not clear what it would change if they were used 'fully' autonomously, among other things because as Ruffo reminds us meaningful human supervision only makes sense if it takes into account the cognitive and reaction time limitations of human operators. ${ }^{25} \mathrm{~A}$ condition that is not always satisfied because the speed of the response is precisely why we resort to such systems of defense. Therefore, if at present autonomous weapons systems are mostly used semi-autonomously, it is essentially for political and military reasons.

Both Mahnken ${ }^{26}$ and Scharre ${ }^{27}$ argue that there is in the American military strong resistance against using these systems in a completely autonomous way. Part of this resistance is due to cultural and social reasons that reflect the composition of the different army corps. For example, the air force that is dominated by pilots is strongly opposed to the development of fully autonomous combat planes and drones. Other reasons are more strictly military, many officers are unsure as to how much these systems can be trusted in real combat situations and insist that they should always be used under human supervision. Finally, there is the question: who should ultimately be in charge? Autonomous systems are competitors with humans as decisions makers, their introduction will produce changes in the structure of the chain of command that will be to the advantage of some and to the disadvantage of others. Therefore, we can expect that their acceptance will also reflect these internal power struggles.

In fact, nobody wants 'fully' autonomous lethal weapons systems and, as Jeangène Vilmer reports, many countries and military experts have explicitly said so. ${ }^{28}$ Actually, such fully autonomous lethal weapons systems already exist, they are human soldiers. In spite of weapon systems makers and many AI researchers' tendency to exaggerate the autonomy of their creation, autonomy means something entirely different when it is applied to a biological entity and when applied to a machine. The autonomy of a biological organism is related to its ability to survive and reproduce, and it is not in any way predefined. To the opposite, it is the maker or programmer who determines what constitutes the autonomy of a robot or AI system: the system is autonomous to the extent that it can do 'by itself what we want it to do. Thus, an autonomous weapon is one that, once activated, does by itself what it was made to do: track and destroy incoming missiles, discover and jam enemy radars, travel to and observe nonstop a predetermined area. It should do nothing else, any departure from its predetermined objectives constitutes a malfunction. To be autonomous for such machines is to be enslaved to a predetermined set of functions and objectives. Autonomy in this sense corresponds to the space that separates an automatic system, like a land mine, whose response is invariably triggered and a more complex one that can by itself modulate its response in view of changing

\footnotetext{
${ }^{25}$ Ruffo, "La robotique militaire: possibilités d'emploi et enjeux éthiques," 33.

26 Th.G. Mahnken, Technology and the American Way of War since 1945.

${ }^{27}$ Scharre, "Autonomous Weapons and Operational Risks."

${ }^{28}$ Jeangène Vilmer, "Diplomatie des armes autonomes: les débats de Genève."
} 
circumstances. That is why there is no absolute clear frontier that separates an automatic system from an autonomous one and why Ruffo proposes to define a robot's autonomy as a meta-capacity, rather than an added capacity. ${ }^{29}$ Unlike, for example a new sensor that allows the robot to do what it could not do before, autonomy is a means of managing what is the robot's behavior.

The difference between these two meanings of autonomy is implicit, though not generally recognized as such, in the many claims that are made concerning the supposed moral superiority of ethical robots over human soldiers. ${ }^{30}$ The central argument in favor of that superiority is always the same: unlike humans, robots will always and in every circumstance - barring technical failures, of course - respect the code of ethics that we inputted in them. Moral or not a robot's autonomy is defined relative to goals that we determine. That is why, whether these weapon systems are used in a fully autonomous mode or semi-autonomously, with a human in the loop, changes little to the important consequences they will have on the structure of the armed forces and on countries ability to project power.

\section{Distance, Territoriality and Hierarchy}

An important aspect of these autonomous weapons systems, according to me, is that they continue a movement of transformation of warfare that began with the development of aerial bombardment. Until then, in order to attack a target inside the enemy's territory you first had to make your way through and preferably conquer whatever part of the territory separated you from your goal. Air bombardments made it possible to inflict severe damage deep inside the enemy's land without having to properly cross the intermediary territory, without any one of your soldiers ever having to set foot there. ${ }^{31}$ From then on, the territory did not need to be conquered in order for the enemy to be forced to a complete surrender. Aerial warfare questions the integrity of the territory, both physically — the distance and space — and legally - a nation's right and ability to offer protection to those who reside on its territory. Autonomous weapons, as we will see, further decrease the territory's importance and negate its meaning even more. ${ }^{32}$

Air bombardment changes the distance between the weapon's operator, the airmen, and the theater of war. Airplane crews and pilots never have to be exactly there, on the ground, where their weapons strike, though the war will be brought to them in the form of enemy planes and air defense. They nonetheless are not where they inflict damage. Moreover, airmen do not have to be continuously in or close to the theater of operations, in trenches or on the front line holding a position. Preferably, their bases are sufficiently removed from where actual combat takes place, that they can only be subject to aerial attacks.

\footnotetext{
29 Ruffo, “La robotique militaire: possibilités d'emploi et enjeux éthiques,” 30.

30 See R.C. Arkin, Governing Lethal Behavior in Autonomous Robots (Boca Raton: CRC Press, 2009) ; S. Umbrello, Ph. Torres, A.F. De Bellis, "The future of war: could lethal autonomous weapons make war more ethical?” AI \& SOCIETY 35 (2020):273-282. Similar claims have been made concerning the moral superiority of autonomous road vehicles over human drivers by E. Awad, S. Dsouza, R. Kim, J. Schultz, J. Heinrich, A. Shariff, J.-F. Bonnefont, I. Rahwan, "The Moral Machine experiment," Nature 563 (2018):59-78. For a criticism regarding autonomous vehicles and ethical lethal robots, see P. Dumouchel, "Philosophy and the Politics of Moral Machines," Journal of Artificial Intelligence Humanities 4 (2019):31-50 ; P. Dumouchel, L. Damiano, Living with robots (Cambridge: Harvard University Press, 2017).

31 A classic illustration of this is the 1999 Nato bombing campaign against Serbia that achieved its objectives without any Nato soldier ever setting foot on Serbian ground.

32 For a similar assessment of the role of 'autonomous' drones, see Steele \& Heinze, "From Smart to Autonomous Weapons."
} 
Autonomous weapons augment this distance between the weapon's operator and the theater of war. This is evident in the case of drones whose pilots and sensor operators are located in Nevada, half-way across the globe from where the strike takes place. It is also clear in the case of SGR-1 robots. The human operator with who it communicates is not where the robot is and does not need to be in anyway nearby. As for the Brimstone and Harpy systems, it is not clear exactly where those who prepare and launch the weapon need to be relative to the commander on the ground who requires its intervention. In the case of the fully autonomous use of the weapon this is even more evident. Those who install and set up the system do not need to be close by when the action takes place. In fact, one could argue that from a military point of view, that is precisely the point. Autonomous weapons save the lives of soldiers removing them from the line of fire as much as possible.

The growing distance between the user and the target of lethal force, especially in the case of drone pilots, has been compared to transforming warfare into a video game. In fact, for centuries, a major theme in the criticism of new weapons has been that as the space that separates the assailant from his victim grows soldiers come to feel very little or no empathy for those they kill. ${ }^{33}$ However, given that we now know that drone pilots sometimes experience PTSD and can suffer 'moral injury' 34 because of the consequences of their actions which take place halfway across the globe, it is not clear that distance alone reduces empathy and it is clear that pilots and sensor operators are well aware that they are not playing a video game.

There is another, completely different consequence of the separation between those who are responsible for the weapon's use and where it brings death and destruction. Autonomous weapons augment the number and the importance of what may be called 'absent warrior combatants.' Unlike those responsible for logistics, these are not non-combatants, but are directly involved in the success or failure of combat operation, and their number and importance grow rather than diminish as the weapons become more autonomous. It is false to believe that autonomous weapons, because they are autonomous, can function on their own. These complex systems are tools for successful warfare and no army or commander on the ground would want them to be autonomous outside of well-defined parameters of action.

Because they are machines that cannot take care of themselves, autonomous weapons systems require maintenance. Because they are powerful and dangerous, like any weapon they are most of the time inactive, or if active under constant monitoring and surveillance. They need to be armed, objectives must be set, and they must be fed data. Furthermore, autonomous weapons systems, for example, unmanned aerial vehicles are only autonomous as part of a larger complex system, that may include reconnaissance planes, radar systems, GPS, communications with soldiers on the ground, a base from which they are to some extent controlled, and so on. It is only with the help of such complex systems that include numerous heterogeneous components that drones are autonomous. These complex systems inevitably include different human specialists, from computer analysts to airmen, from radar operators on a ship or plane to drone pilots in Nevada or closer to the theater of operations. All of them together with the various automated parts of the system bring a crucial contribution to the success of operations on the ground.

In other words, the growing distance between the operator of the weapon and where the violent action takes place which is at the heart of the development of autonomous weapons systems augments rather than it reduces the number of people who are involved in any given

${ }^{33}$ Derriennic argues, using historical examples, that the claim that modern weapons and the distance they create tends to make war more deadly is clearly false. See J.-P. Derriennic, Les guerres civiles (Paris: Presses de Sciences PO, 2001).

${ }^{34}$ Enemark, "Drones, risk and moral injury." 
operation. It also creates a class of 'absent warrior combatants.' 'Absent' because they are not physically present where the violent action takes place. 'Warrior combatants' because they are directly involved in the use of force, and, as in the case of drone pilots, these individuals who are essential to the success of the mission may or may not be members of the armed forces. This transformation is important, both because it blurs the line that separates soldiers from civilian operators and because it will inevitably have consequences — which are hard to foresee - on the status of soldiers on the ground ; those who actually combat and who unlike far removed operators are immediately and inevitably confronted to the results of whatever action is taken.

Autonomous weapons because they can discriminate more finely and home in on very precise targets challenge territoriality in a new and more radical way than classic aerial warfare ever did. Their ability to target individuals has encouraged powerful states to engage in political assassinations, extra-judicial killings in other countries. Secret agents on the ground can be captured, planes or helicopters can be shot down. However, drones and rockets insure impunity, not because they can penetrate the territory without being noticed, nor because they strike stealthily and therefore we cannot easily attribute responsibility for a drone attack; to the opposite, they insure impunity because autonomous and semi-autonomous weapons set the bar of responsibility to high.

When an American drone attack kills a terrorist commander on the territory of another nation with which it is not at war, say Pakistan, the American army and government immediately claim success and recognize their responsibility. Or when an American drone operating in Yemen kills an American citizen turned Al Qaeda, the American government proclaims its responsibility. It does not seek, but it claims impunity. It does not say, 'we did not transgress international laws that protects the sovereignty of every country over its territory,' rather, it asserts that in its fight against terrorist it is not bound by these laws. The reasons why the American government so brazenly defies the international order is not simply that the United States is a very powerful country, ${ }^{35}$ but also that unlike helicopter pilots or secret agents, drones cannot be brought to trial. They cannot be imprisoned or executed. In consequence, the only ones that can be charged or blamed for the action are too high up the chain of command to be targets of immediate retaliation or brought to justice. There is little prospect for any country being able to bring to court the Commander in Chief of the American Armed Forces or the Joint Chief of Staff. The problem created by the use of such weapons is not that no one is responsible, but that the responsibility is pushed up the chain of command, so that those who claim responsible are unlikely to have to account for their action. The result is not a responsibility gap, but an accountability gap.

The real issue concerning autonomous weapons and responsibility is not as many believe that we cannot know who is responsible ${ }^{36}$ or that we are unable to attribute responsibility in the case of such complex systems, ${ }^{37}$ but that they drive responsibility up the chain of

\footnotetext{
35 To the opposite, when the Russians secret services poison a dissident in the UK, Moscow protests its innocence, claiming that it never had anything to do with it, and that the suspects are tourists and do not belong to the Russian secret services. Yet the Russian Federation is also a very powerful country. The difference here lies mainly in the political situation and the fact that such claims are partially directed towards a country's own population. The American government wants to show to its citizens what it does to protect them from terrorism and simultaneously to reinforce its image as the most powerful country. The Russian want send a contradictory message. First to convince those who supports the government in power that the country is the victim of unfounded accusations and second to remind dissidents that they are nowhere safe. Denying what is evident is an excellent way to do that.

36 Sparrow, "Killer Robots."

37 M. Coeckelgergh, "From Killer Machines to Doctrine and Swarms or Why Military Ethics is not (necessarily) about Robots,” Philosophy \& Technology 24 (2011) 24:269-278. L. Floridi, J.W. Sanders, “On
} 
command to a point where those involved can claim responsibility with impunity. Autonomous weapon systems centralize authority and responsibility, exacerbating a trend that has always been present in a hierarchical social organization like the armed forces. As Mahnken remarks:

The accessibility of global communication exacerbated the trend towards centralized military operations. It produced a shared picture at all levels and permitted "command at distance." Not only did it enable more timely operations, but it also allowed senior leaders to become enmeshed in the minutiae of operational planning and execution... (which) at times proved to be a distraction or even an irresistible temptation to micromanagement. ${ }^{38}$

These weapons system are the offspring of global communication and they cannot survive without their progenitor. They centralize the power of decision. They make possible the micromanagement of ongoing operations by senior figures, because global communication allows them to see directly what is happening on the ground, even if they are thousands of kilometers away, and because autonomous weapons give them the ability to act directly in the theater of operations, without having to go through the normal chain of command. That is without having to deal with subordinates, who may be... insubordinate. Autonomous weapons systems lead to a concentration of the power to decide the use of lethal force, not to the disappearance of responsibility. Another way of expressing this is that lethal autonomous weapons systems tend to replace questions of jus in bello by the only issue of jus ad bellum. That is to replace questions about how a particular mission was carried out to whether or not the war on terror is justified.

\section{Special Forces}

In the last ten or fifteen years, all engagements of Western armed forces took place far beyond the limits of these countries' territories, mostly in the Middle East and in Africa. Essentially these international operations relied on special forces, small numbers of highly trained soldiers equipped with the most modern weapons and communication systems. In places like Libya and Syria the strategy further has essentially been one of co-opting local militia and rebel forces as boots on the ground, promising them access to fire power like they could never imagine before. This approach allowed a number of countries, for example, France, the UK, Russia, the USA, but also Saudi-Arabia and the UAE to carry on a series of undeclared war.

Small special forces that are able to request the support of powerful autonomous or automated weapons permits countries to engage in what may be described as 'politically silent wars.' That is wars that do not need to become part of the country's political discussion and of which numerous citizens remain completely unaware, because few soldiers on the ground means fewer casualties among one's troop and because of the widely shared prejudice that special operations require secrecy. The use of such special forces has now become a preferred way for powerful countries to project their power abroad. It allows them to do it while

the Morality of Artificial Agents," Mind and Macbine 14/3 (2004):349-379. The claim that that we are unable to attribute responsibility in the case of such complex systems rests, according to me, on a conceptual mistake, on the confusion of moral and legal responsibility with causality. The idea of distributed responsibility in current ethic theory raises a different issue, contrary to what these authors seem to think.

38 Mahnken, Technology and the American Way of War since 1945, 203. 
avoiding political discussions concerning the legality and justification of their foreign engagement, often misrepresenting the consequences of what is going on. ${ }^{39}$

Autonomous weapons change the politics of war. First, it may be argued that such weapons mean that less soldiers of one's nation will die in combat, which is certainly a good thing. It also reduces in consequence public opposition to poorly justified military engagements, which is less of a good thing. Second, the use of these powerful weapon systems that depend on absent warrior combatant already has led and will more and more lead to replacing the army of citizens by an elite force of highly trained warriors. Members of this force may be part of the countries armed forces, but that does not need to be the case as governments also outsource this work to various private securities companies. In both cases, these soldiers have at their disposal the most modern weapons. Historically, an important separation and difference between specialists of violence and the average population has never been a good recipe for democracy.

A central consequence of killer robots and autonomous weapons systems is not that nobody will be responsible for killing, but that fewer persons will be responsible, though as in environmental pollution a greater number of persons will be causally involved. Autonomous weapons systems, whether lethal or not, do not abolish but modify the structure of the decision process that leads to moral or legal responsibility. Simultaneously, they redraw the borders of sovereignty and dissolve territoriality inasmuch as they allow major countries to target individuals, terrorists, political enemies or dissidents, anywhere. In this world without borders, there is no place to hide. Some will argue that this is precisely the strategy adopted by terrorist groups and that we need to adapt if we are to succeed. It is certainly the case that terrorists recognize neither sovereignty nor borders, that they seek to convince that they can strike anywhere, anytime, that no one is safe. However, this mimetic relation, which seeks to justify our actions in relation to theirs, clearly illustrates that autonomous weapons systems are not mere technological innovations, but responses to changing political and social situations. These responses should be addressed as such, if our societies do not want to become like those we are fighting in our effort to destroy them.

Autonomous weapons systems, lethal or not will change and are already changing the political landscape just has they have changed the theater of operations. It is not so much that they make war easier, as it is sometimes feared. Rather, they make possible new ways for countries to engage in violence. Ways that are neither like the two world wars of the $20^{\text {th }}$ century, nor like colonial wars, whether the wars of colonial conquest or of independence.

\section{Acknowledgements}

I want to thank Alexander Leveringhaus and an anonymous referee for their very useful comments on a previous version of this article.

\section{References}

Arkin, R.C. Governing Lethal Behavior in Autonomous Robots. Boca Raton: CRC Press, 2009.

Awad, E., Dsouza, S., Kim, R., Schultz, J., Heinrich, J., Shariff, A., Bonnefont, J.-F., Rahwan, I. “The Moral Machine experiment.” Nature 563 (2018): 59-78. https://doi.org/10.1038/ s41586-018-0637-6.

Bedau, M., Parke, E.C. (eds.). The Ethics of Protocells. Cambridge, Mass.: MIT Press, 2009.

\footnotetext{
39 Enemark, "On the responsible use of armed drones: the prospective of moral responsibilities of states."
} 
Coeckelgergh, M. "From Killer Machines to Doctrine and Swarms or Why Military Ethics is not (necessarily) about Robots." Philosophy \& Technology 24 (2011) 24:269-278. DOI 10.1007/s13347-011-0019-6.

Crootof, R. "Killer Robots are Here: Legal and Policy Implications." Cardozo Law Review (January 2015) : 1837-1915.

Defense, directive 3000.09. "Autonomy in weapons systems" (November 2, 2012): 13-14 http://www.dtic.mil/whs/directives/cores/pdf/300009p.pdf .

Derriennic, J.-P. Les guerres civiles. Paris: Presses de Sciences PO, 2001.

Dewyn, M. (2020) "La théorie de la guerre juste et l'utilisation des drones armés: l'application des principes du jus ad bellum." In Robotisation des armées, enjeux militaires, étbique et légaux, ed. C. Ceulemans, M. Dewyn, D. Lambert, M-d-N. Ruffo, P. Warnotte, 83-104. Paris: Economica, 2020.

Dumouchel, P. "Philosophy and the Politics of Moral Machines." Journal of Artificial Intelligence Humanities 4 (2019):31-50.

Dumouchel, P., Damiano, L. Living with robots. Cambridge: Harvard University Press, 2017.

Enemark, C. "On the responsible use of armed drones: the prospective of moral responsibilities of states." The International Journal of Human Rights 24 (2019): 868-888. DOI: $10.1080 / 13642987.2019 .1690464$.

Enemark, C. "Drones, risk and moral injury." Critical Military Studies 5/2 (2019): 150-167.

Floridi, L., Sanders, J.W. "On the Morality of Artificial Agents." Mind and Machine 14/3 (2004):349-379.

Gubrud, M.A. "Stopping Killer Robots." Bulletin of Atomic Scientists 70/1 (2014): 32-42. DOI: 10.1177/0096340213516745

Jeangène Vilmer, J.-B. "Terminator Ethics: Faut-il interdire les 'robots tueurs??" Politique Etrangère 4 (2014):151-167.

—. "Diplomatie des armes autonomes: les débats de Genève." Politique Etrangère 3 (2016):119-130.

Lambert, D. "La théorie de la guerre juste et les robots armés." In Robotisation des armées, enjeux militaires, éthique et légaux, 165-178. Paris: Economica, 2020.

Liu, H-Y. "Categorization and Legality of Autonomous and Remote Weapons System." International Review of the Red Cross 94 (June 2012): 627-652. DOI: 10.1017/ S181638311300012X.

Mahnken, Th.G. Technology and the American Way of War since 1945. New York: Columbia University Press, 2010.

O'Mathuna, D. Nanoethics big ethical issues with small technology. London: Continuum, 2009.

Scharre, P. "Autonomous Weapons and Operational Risks." Center for New American Security (2016).

- Army of None Autonomous Weapons and the Future of War. New York: Norton and Company, 2018.

Schogol, J. "Contract jobs for drone pilots are often overseas." Air Force Times (April 21, 2015). www.airforcetimes.com/news/your-air-force/2015/04/21/contract-jobs-for-dro ne-pilots-are-often-overseas/.

Sparrow, R. "Killer Robots." Journal of Applied Pbilosophy 24/1 (2007): 62-77.

Steele, B.J., Heinze, E.A. "From Smart to Autonomous Weapons." In The Future of Just War. New Critical Essays, ed. Gentry \& Eckert, 98-114. Athens, GE: University of Georgia Press, 2014.

Ruffo, M.-d-N. "La robotique militaire: possibilités d'emploi et enjeux éthiques." In Robotisation des Armées enjeux militaires, éthiques et légaux, 19-38. Paris: Economica, 2020. 
Umbrello, S., Torres, Ph., De Bellis, A.F. "The future of war: could lethal autonomous weapons make war more ethical?” AI \& SOCIETY 35 (2020): 273-282. doi.org/10.1007/s00146-019-00879-x.

Wallach, W., Allen, C. Moral Machines Teaching Robots Right from Wrong. Oxford: Oxford University Press, 2009.

Warnotte, P. "SALA: aspects juridiques." In Robotisation des Armées enjeux militaires, éthiques et légaux, 127-146. Paris: Economica, 2020. 